\title{
THE RELEASE OF ALUMINUM FROM ALUMINOSILICATE MINERALS. I. KINETICS
}

\author{
F. CABrera* and O. TAllibudeen \\ Soils and Plant Nutrition Department, Rothamsted Experimental Station \\ Harpenden, Herts. England AL5 2JQ \\ (Received 29 August 1977)
}

\begin{abstract}
The rates of release of $\mathrm{Al}$ by $\mathrm{M} \mathrm{NH}_{4} \mathrm{NO}_{3}(\mathrm{pH} 3)$ from minerals saturated with $\mathrm{Al}$ ions at $\mathrm{pH} 3$ suggest that $\mathrm{Al}$ ions migrated from the surface layers and the matrix cores of kaolinite, montmorillonite, illite, and biotite, but only from the matrix core of muscovite mica. From the $0.25-0.5 \mu \mathrm{m}$ kaolinite and montmorillonite, part of the 'surface' Al is released 'instantaneously' and the rest by first order kinetics, but the coarse 1.5-2.5 $\mu \mathrm{m}$ kaolinite has only the former component. From illite and biotite, 'surface' Al is released by 'bulk diffusion' kinetics suggesting the existence of disturbed peripheral layers of finite thickness. The diffusion coefficients, $D_{m}$, for the matrix core follow the trend: mica $\approx$ biotite $>$ illite $>$ montmorillonite $>$ kaolinite.

Based on models proposed in previous work, the ionic composition of the 'surface' Al is calculated. This shows that (1) this composition varies according to the mineral from 3 to $100 \% \mathrm{Al}^{3+}$, the remainder being in the hydrolyzed form, and (2) the apparent hydrolysis constants are different for each mineral and significantly different from those of $\mathrm{Al}$ ions in solution.
\end{abstract}

Key Words—Aluminum, Biotite, Illite, Kaolinite, Montmorillonite.

\section{INTRODUCTION}

The determination of exchangeable $\mathrm{Al}$ in acid soils and its differentiation from slowly released nonexchangeable $\mathrm{Al}$ has occupied the attention of many research workers. A method commonly used is successive extraction with an unbuffered salt solution (e.g., $\mathrm{KCl}, \mathrm{NH}_{4} \mathrm{Cl}, \mathrm{NH}_{4} \mathrm{NO}_{3}$ ) adjusted to the soil $\mathrm{pH}$ (Skeen and Sumner, 1967; Sivasubramaniam and Talibudeen, 1972; Prakash and Bhasker, 1974; Cabrera and Talibudeen, 1977). Bache and Sharp (1976a) attributed this slowly released $\mathrm{Al}$ to disordered aluminosilicates, $\mathrm{Al}$ interlayers in vermiculite clays and organic $\mathrm{Al} \mathrm{com-}$ plexes in soils. Not much attention has been paid however to similar measurements of the kinetics of $\mathrm{Al}$ extraction from pure minerals such that rate parameters can be evaluated, especially for the 'slow release' reaction, and related to such measurements with acid soils.

The total exchangeable cations, including $\mathrm{Al}$, displaced by unbuffered salt solutions from acid soils has been shown to be larger than the CEC measured by one of the standard methods ( $\mathrm{Lin}$ and Coleman, 1960; Bache, 1970; Lim and Talibudeen, 1975). This suggests that displaced $\mathrm{Al}$ ions have a charge $<3+$ per $\mathrm{Al}$ atom, i.e., they are adsorbed as partially hydrolyzed $\mathrm{Al}$ ions on mineral surfaces. From studies on the composition of the solution of $\mathrm{Al}$ extracted from acid soils and clays, the existence of polymeric $\mathrm{Al}$ species on mineral surfaces has been suggested (Chakravarti and Talibudeen, 1961; Bache, 1974; Dalal, 1975; Smith and Emerson,

\footnotetext{
* Permanent address: Centro de Edafología y Biología Aplicada del Cuarto (C.S.I.C.), Sevilla, Spain.
}

1976). Also Brown and Newman (1973) demonstrated the adsorption by bentonite of a basic cation with $\mathrm{OH} /$ $\mathrm{Al}$ ratio of 2.5. (For a comprehensive review see Coulter, 1969). More recently Bache and Sharp (1976b) were able to distinguish analytically between mononuclear and polynuclear $\mathrm{Al}$ ions in soil solutions.

The work described hitherto (except Lin and Coleman, 1960; Smith and Emerson, 1976) has been on natural materials whose surface properties concerning adsorbed Al are affected by their history. In our measurements we pretreated the various minerals so that they had a common background before kinetic extractions of $\mathrm{Al}$ commenced.

\section{MATERIALS AND METHODS}

\section{Minerals}

Some properties of the minerals used in this work are given in Table 1. Specific surface areas (SA) were determined by the adsorption of ethylene glycol vapor (Rawson, 1969). Cation exchange capacities (CEC) were determined by $\mathrm{NH}_{4}{ }^{+}$adsorption as described below.

\section{Al-saturation of the minerals}

Ten milliliters of $0.1 \mathrm{~N} \mathrm{Al}\left(\mathrm{NO}_{3}\right)_{3}$ solution adjusted to $\mathrm{pH} \mathrm{3}$, were added to $0.5 \mathrm{~g}$ of the air-dry mineral with $0.2 \mathrm{~g}$ of glass beads ( $<100 \mathrm{mesh})$ in weighed $15 \mathrm{ml}$ polypropylene centrifuge tubes. After shaking overnight, the tubes were centrifuged at $20,000 \mathrm{~g}$ for 30 to $90 \mathrm{~min}$ at $20 \pm 1{ }^{\circ} \mathrm{C}$, and the supernatant solution rejected. This treatment was repeated 3 times to ensure that the concentration and $\mathrm{pH}$ of the final supernatant were those of the added Al solution. The tubes were then reweighed to determine the amount of entrained solution. All experiments were done in triplicate at $20 \pm 2{ }^{\circ} \mathrm{C}$. 


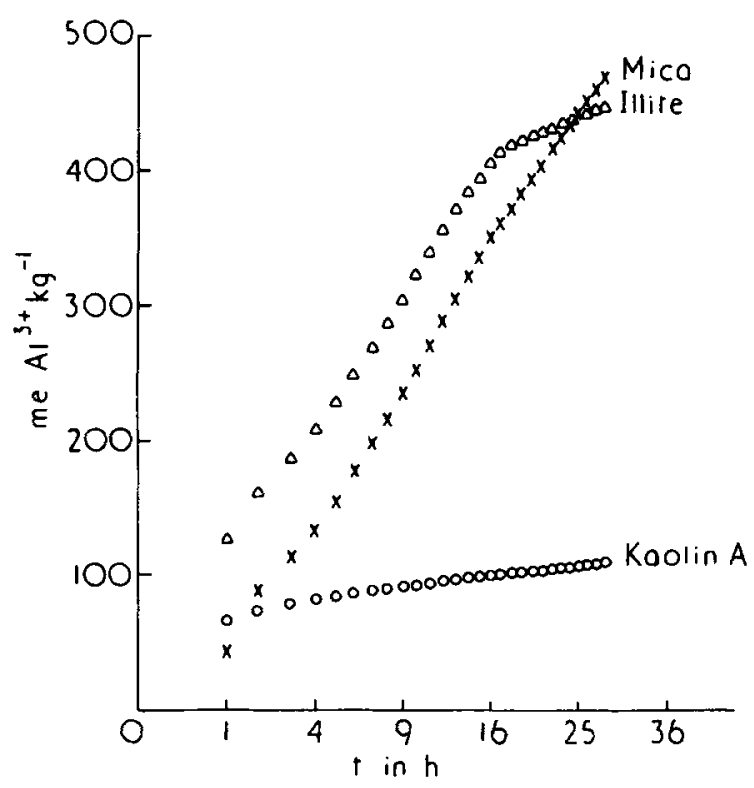

Fig. 1. Cumulative amounts of $\mathrm{Al}$ extracted (in meq $\mathrm{Al}^{3+} \mathrm{kg}^{-1}$ ) with time by $\mathrm{M} \mathrm{NH}_{4} \mathrm{NO}_{3}$ (pH 3.0) from kaolinite $\mathrm{A}$, muscovite mica, and Fithian illite saturated with $\mathrm{Al}^{3+}$ ions at $\mathrm{pH} 3.0$.

\section{Rates of Al extraction}

The Al-saturated minerals were successively extracted with $10 \mathrm{ml}$ aliquots of $1.0 \mathrm{M} \mathrm{NH}_{4} \mathrm{NO}_{3}$ at $\mathrm{pH} 3$ by shaking for $1 \mathrm{hr}$ on a Rolamix shaker, centrifuging at $17,000 \mathrm{rpm}$ and decanting the supernatant solution for $\mathrm{Al}$ analysis and $\mathrm{pH}$ measurement. The tubes were then reweighed to determine the Al solution entrained in the solid. The Al extracted at each sampling time was obtained by correcting the total $\mathrm{Al}$ found in solution for this entrained $\mathrm{Al}$. The whole process was repeated up to $28 \mathrm{hr}$. The $\mathrm{NH}_{4}$-saturated minerals were then washed several times with $10 \mathrm{ml}$ aliquots of $95 \%$ ethanol to remove the entrained $\mathrm{NH}_{4} \mathrm{NO}_{3}$ solution. The total $\mathrm{N}$ in the solids was determined after Kjeldahl digestion to give the CEC. Aluminum in the supernatant solutions was analyzed for by the method of Jayman and Sivasubramaniam (1974).

\section{RESULTS AND DISCUSSION}

\section{Rate of Al extraction}

For all the minerals except mica, the curvilinear plot 'cumulative $\mathrm{Al}$ extracted, $\mathrm{Al}_{t}$ vs. (time) ${ }^{1 / 2}$ ' became linear after some time depending on the nature of the mineral. Kaolin A illustrates the behavior of kaolin B and montmorillonite, and illite that of biotite (Figure 1). These curves represent rate processes governing the extraction of at least two categories of $\mathrm{Al}$ in the solid (i.e., Al on the mineral surfaces and $\mathrm{Al}$ in the octahedral layers; Figure 2a). The linear part of the plot at $t>4$ hr for kaolin $A$ and $t>16 \mathrm{hr}$ for illite (Figure 1) suggests that the slower process (Table 2) results from the exchange diffusion of protons inwards and Al to the surface through the octahedral layer. The Al exchanging from the surface layers at time $t, \mathrm{Al}_{t}{ }^{(s)}$, is obtained by subtracting from $\mathrm{Al}_{\mathrm{t}}$, that associated with the slower process, $\mathrm{Al}_{t}{ }^{(m)}$. The total $\mathrm{Al}$ released thus, $\mathrm{Al}_{\infty}{ }^{\left({ }^{(}\right)}$, is the intercept of the linear part of ' $\mathrm{Al}_{t}: t^{1 / 2}$ ' plot.

The release of $\mathrm{Al}$ from surface sites (velocity constant $k_{s}$ ) by cation exchange with a large excess of $\mathrm{NH}_{4}^{+}$ can be expressed by the first order equation

$$
d\left[\left(\mathrm{Al}_{\infty}{ }^{(s)}-\mathrm{Al}_{f}^{(s)}\right) / \mathrm{Al}_{\infty}{ }^{(s)}\right] / d t=-k_{s}\left(\mathrm{Al}_{\infty}{ }^{(s)}-\mathrm{Al}_{f}^{(s)}\right)
$$

The integrated form (boundary conditions $t=0, \infty$; $\left(\mathrm{Al}_{\infty}{ }^{(s)}-\mathrm{Al}_{t}^{(s)} / \mathrm{Al}_{\infty}(s)=1,0\right)$ gives a linear plot of 'In $\left(\mathrm{Al}_{\infty}{ }^{(s)}-\mathrm{Al}_{t}{ }^{s} / \mathrm{Al}_{\infty}{ }^{(s)}: t\right.$ ' with zero intercept. Such a straight line plot is obtained for kaolin A and montmorillonite, but with a finite intercept indicating a very rapid exchange reaction before $1 \mathrm{hr}$, which accounts for $79 \%$ and $85 \%$ of the 'surface' $\mathrm{Al}$ in kaolinite $A$ and montmorillonite respectively. The first order rate constants are therefore calculated after correcting $\mathrm{Al}_{\infty}{ }^{(s)}$ and $\mathrm{Al}_{t}^{(s)}$ for this $\mathrm{Al}$ released 'instantaneously' by our method of measurement (Table 2). For the coarse kaolin B, nearly all (ca. 98\%) of this 'surface' Al exchanges out 'instantaneously'.

The release of such rapidly exchanging 'surface' Al from illite and biotite does not follow equation (1). However, the $\mathrm{Al}_{t}^{(s)}: t^{1 / 2}$ plot is linear up to 17 and 10

Table 1. Description of minerals.

\begin{tabular}{|c|c|c|c|c|c|c|}
\hline \multirow[b]{2}{*}{ Mineral } & \multirow[b]{2}{*}{$\begin{array}{l}\text { Particle } \\
\text { size } \mu \mathrm{m}\end{array}$} & \multirow[b]{2}{*}{$\begin{array}{c}\% \mathrm{H}_{2} \mathrm{O} \text { in air-dry } \\
\text { mineral (a) }\end{array}$} & \multirow[b]{2}{*}{$\underset{\text { (b) }}{S A} m^{2 / g}$} & \multirow[b]{2}{*}{$\begin{array}{c}\text { CEC meq } \\
\mathbf{k g}^{-1} \text { (a) }\end{array}$} & \multicolumn{2}{|c|}{ Surface charge density } \\
\hline & & & & & $\underset{\times 10^{4}}{\operatorname{meq~m}}$ & $\begin{array}{l}\mathrm{nm}^{2} \text { per unit } \\
\text { charge }\end{array}$ \\
\hline Kaolinite A (St. Austell) & $0.25-0.5$ & 1.0 & 87 & 76 & 9 & 1.9 \\
\hline Kaolinite B (St. Austell) & $1.5-2.5$ & 0.6 & 67 & 32 & 5 & 3.5 \\
\hline Montmorillonite (Upton) & $0.2-1$ & 8.9 & 804 & 733 & 9 & 1.8 \\
\hline Mica (muscovite) & $>1$ & 0.5 & 19 & 124 & 65 & 0.25 \\
\hline Illite (Fithian No. 35) & $<1$ & 3.5 & 251 & 237 & 9 & 1.8 \\
\hline Biotite (Ontario) & $<50$ & 0.8 & 12 & 47 & 39 & 0.42 \\
\hline
\end{tabular}

(a) On dry weight at $110^{\circ} \mathrm{C}$ over $\mathrm{SiO}_{2}$ gel

(b) On dry weight at $60^{\circ} \mathrm{C}$ over $\mathrm{SiO}_{2}$ gel. 


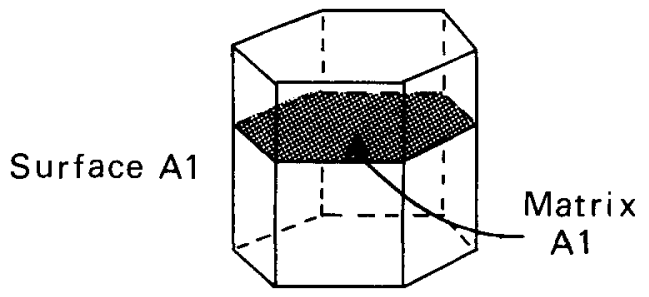

(a)

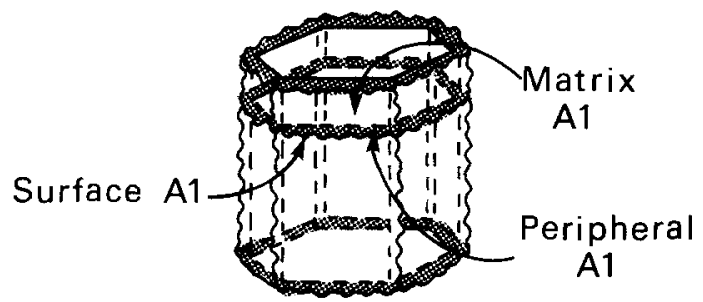

(b)

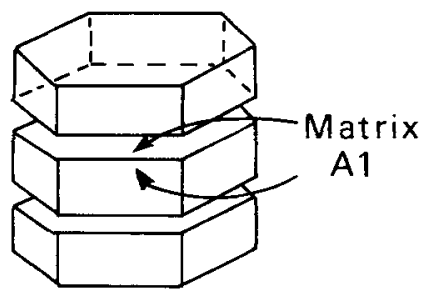

Fig. 2. Idealized diagrammatic representations of (a) 'surface' and 'matrix' regions in kaolinites $\mathrm{A}$ and $\mathrm{B}$ and montmorillonite; (b) surface, peripheral, and matrix regions in illite and biotite; (c) comminution of mica during extraction.

hr of extraction, respectively, suggesting that 'surface' $\mathrm{Al}$ is released from peripheral region of finite thickness by a 'bulk diffusion' process (Table 2 and Figure $2 b$ ). The intercept of the ' $\mathrm{Al}_{t}^{(s)}: t^{1 / 2}$ ' plot is practically zero for biotite and $21 \mathrm{meq} \mathrm{Al}^{3+} \mathrm{kg}^{-1}$ for illite, indicating that in illite, about $7 \%$ of the 'surface' $\mathrm{Al}$ is released 'instantaneously.' Therefore, little or no 'surface' Al exchanges for $\mathrm{NH}_{4}{ }^{+}$ions in these minerals. The possible nature of $\mathrm{Al}$ ions released from these minerals in the initial faster reaction is discussed in the next section.

Diffusion in the peripheral region of illite and biotite and in the mineral matrix of all the minerals can be represented by the diffusion equation (2), adapted from Crank (1956). For cylindrically shaped mineral particles, the 'non-steady state' diffusion of Al ions radially outwards, where a vanishingly small concentration of $\mathrm{Al}$ is maintained at the surface, is given by

$$
\frac{M_{t}}{t}=\frac{4 M_{\infty}}{\pi^{1 / 2}}\left(\frac{D}{a^{2}}\right)^{1 / 2} \frac{1}{t^{1 / 2}}-\frac{D M_{\infty}}{a^{2}}
$$

for small values of $t$, where $M_{t}$ and $M_{\infty}$ are the amounts of $\mathrm{Al}$ at time $t$ and on completion of the process, $a$ is the radius of the cylinder and $D$ the diffusion coefficient. The ' $M_{t} / t: 1 / t^{1 / 2}$ ' plot enables $D$ to be calculated from the slope $\left(4 M_{\infty} / \pi^{1 / 2}\right)\left(D / a^{2}\right)^{1 / 2}$ if $a$ and $M_{\infty}$ are known. The cylinder radius a (Table 3 ) was calculated from the specific surface area (SA, Table 1), the density of the minerals (taken as $2.65 \mathrm{~g} \mathrm{~cm}^{-3}$ ) and assuming diameter: thickness ratios of 4 for kaolinite and 10 for smectite and micas (Talibudeen and Weir, 1972). Values of $M_{\infty}$ for the diffusion of Al from the surface layers of illite and biotite, $\mathrm{Al}_{\infty}{ }^{(\mathrm{s})}$, were determined from the intercept of the ' $\mathrm{Al}_{\mathrm{t}}: \mathrm{t}^{1 / 2}$ ' plot as described earlier. (For illite it was corrected for the $21 \mathrm{meq} \mathrm{Al}^{3+} \mathrm{kg}^{-1}$ of 'surface' Al 'instantaneously' released.) For the Al diffusing from the mineral matrix, $M_{\infty}$ was taken as the total $\mathrm{Al}$ content of each mineral, $\mathrm{Al}_{T}$ (Table 3).

Diffusion coefficients of $\mathrm{Al}$ in the surface layers of illite and biotite, $D_{s}$, are, respectively, about $10^{4}$ and $10^{2}$ times larger than their corresponding values for the mineral matrix, $D_{m}$ (Table 2). The $D_{s}$ value for illite is larger than for biotite suggesting that the $\mathrm{Al}$ in the peripheral layer is more easily dissolved from illite than

Table 2. Kinetics of $\mathrm{Al}$ extraction (in meq $\mathrm{kg}^{-1}$ ) by $\mathrm{M} \mathrm{NH}_{4} \mathrm{NO}_{3}$ at $\mathrm{pH} 3$ by batch 'leaching.'

\begin{tabular}{|c|c|c|c|c|c|}
\hline \multirow[b]{2}{*}{ Mineral } & & \multicolumn{2}{|c|}{ 'Fast' process } & \multicolumn{2}{|c|}{ 'Slow' process } \\
\hline & & Regression & Intercept & Regression & Intercept \\
\hline & & Equation (1) & $\ln \left(\mathrm{Al}_{\mathrm{l}} / \mathrm{A \textrm {A } _ { \infty }}\right): t$ & Equation (2) & $\mathrm{Al}_{4}: t^{1 / 2}$ \\
\hline \multirow{3}{*}{\multicolumn{2}{|c|}{$\begin{array}{l}\text { Kaolin A } \\
\text { Kaolin B } \\
\text { Montmorillonite }\end{array}$}} & -0.31 & -0.18 & 7.6 & 68.4 \\
\hline & & \multicolumn{2}{|c|}{ insignificant } & 5.9 & 24.1 \\
\hline & & -0.26 & -0.01 & 11.5 & 805.0 \\
\hline \multirow{6}{*}{$\begin{array}{l}\text { Illite } \\
\text { Biotite } \\
\text { Mica }\end{array}$} & & Equation (2) & $\mathrm{Al}_{1}: t^{1 / 2}$ & Equation (2) & $\mathrm{Al}_{t}: t^{1 / 2}$ \\
\hline & & 69.5 & 21.0 & 29.7 & 290.8 \\
\hline & & 65.4 & -5.7 & 14.1 & 231.7 \\
\hline & $<5 \mathrm{hr}$ & - & - & 84.6 & -34.2 \\
\hline & $5-16 \mathrm{hr}$ & - & - & 113.0 & -102.9 \\
\hline & $>16 \mathrm{hr}$ & - & - & 90.8 & -12.8 \\
\hline
\end{tabular}

Note: For all correlations, $\mathrm{r}^{2}>0.980^{* * *}$. 
Table 3. Calculated Al content, 'equivalent cylinder' radius, and characteristic constants of the kinetics of $\mathrm{Al}$ extraction with $\mathrm{M} \mathrm{NH}_{4} \mathrm{NO}_{3}$ (pH 3).

\begin{tabular}{|c|c|c|c|c|c|}
\hline & $\begin{array}{l}\text { "a" cylindrical } \\
\text { radius } \times 10^{5}\end{array}$ & $\begin{array}{c}\mathrm{Al}_{\mathrm{Y}} \text { mol eq } \\
\mathrm{kg}^{-1}(\mathrm{~b})\end{array}$ & 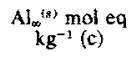 & $\begin{array}{l}k_{\mathrm{k}} \mathrm{s}^{-1} \\
\times 10^{5}\end{array}$ & $\begin{array}{c}D_{m} \mathrm{~cm}^{2} \mathrm{~s}^{-1} \\
\times 10^{23}\end{array}$ \\
\hline Kaolin A & 2.6 & 23,200 & 70 & 8.6 & 3.6 \\
\hline Kaolin B & 3.4 & 23,200 & 25 & - & 3.8 \\
\hline \multirow[t]{2}{*}{ Montmorillonite } & $4.5(a)$ & 11,900 & 888 & 7.2 & 84 \\
\hline & & & & $\begin{array}{c}D_{\mathrm{s}} \\
\mathrm{cm}^{2} \mathrm{~s}^{-1} \\
\times 10^{17} \\
\end{array}$ & $\begin{array}{c}D_{m} \\
\mathrm{~cm}^{2} \mathrm{~s}^{-1} \\
\times 10^{20} \\
\end{array}$ \\
\hline Mica & 24 & 22,700 & - & - & 49 \\
\hline Illite & $11(\mathrm{a})$ & 15,200 & 319 & 34 & 2.1 \\
\hline Biotite & 37 & 6700 & 230 & 6.7 & 38 \\
\hline
\end{tabular}

(a) Radius considering the external surface area.

(b) Approxiniate values calculated from theoretical composition taken from various sources.

(c) On dry weight at $110^{\circ} \mathrm{C}$ over $\mathrm{SiO}_{2}$ gel.

from biotite. For the slow process, $D_{m}$ values (Table 3) follow the trend: biotite $>$ illite $>$ montmorillonite $>$ kaolin $\mathrm{B} \simeq$ kaolin $\mathrm{A}$, indicating that the dissolution of the matrix $\mathrm{Al}$ in $\mathrm{M} \mathrm{NH}_{4} \mathrm{NO}_{3}$ of $\mathrm{pH} 3$ decreases in this order. The $D_{m}$ value for biotite is $10^{4}$ times greater than for kaolinite. This sequence coincides with the weathering sequence given by Jackson et al. (1948). One of the factors enumerated by Jackson et al. (1952), responsible for this weathering sequence, is the "de-alumination" of the aluminosilicates.

Mica behaves differently from the other minerals. The initially constant slope at $t<5 \mathrm{hr}$ of the ' $\mathrm{Al}_{t}: t^{1 / 22}$, plot increases up to $16 \mathrm{hr}$ of extraction and then becomes constant (Table 2). We suggest that this initial increase is caused by the creation of new edge surfaces during the treatment with $\mathrm{M} \mathrm{NH}_{4} \mathrm{NO}_{3}$ at $\mathrm{pH} 3$ by the exfoliation and splitting of mica sheets (Figure 2). So the diffusion coefficient, $D_{m}$, calculated (Table 3 ) is for Al released at times $>16 \mathrm{hr}$ with $M_{\infty}$ equal to the total $\mathrm{Al}$ in the mica, and is the same as that for biotite.

Ionic composition of Al sorbed in 'surface' layers

The $\mathrm{pH}$ of the extracts were initially higher than that of the extractant, decreasing gradually to a value approximately constant and slightly different for each mineral (Table 4 and Figure 3). We attribute this initial increase of $\mathrm{pH}$ to more basic forms of $\mathrm{Al}$ ions in the surface regions of the minerals than expected at $\mathrm{pH} 3$ in solution (see also Chakravarti and Talibudeen, 1961, in clay minerals; Lim and Talibudeen, 1975, and Cabrera and Talibudeen, 1977, in acid soils). The values of surface-held $\mathrm{Al}$ expressed as meq $\mathrm{Al}^{3+}$ are higher than the corresponding CEC, except with both kaolins for which they are equal within experimental error (Table 1 and 3).

To calculate the proportions of various ionic Al species that could explain these observations, we have tested three models. (i) Model A: Using the simplest, unpolymerized, forms of $\mathrm{Al}^{3+}$ and $\mathrm{Al}(\mathrm{OH})^{2+}$ as the two more important species at $\mathrm{pH} 3-4$, together with CEC and surface-held Al values, two simultaneous equations were formulated. By solving these, positive values of $\mathrm{Al}^{3+}$ and $\mathrm{AlOH}^{2+}$ were obtained (Table 4) with montmorillonite and illite. With biotite an indeterminate negative value for $\mathrm{Al}^{3+}$ was obtained; indeterminate amounts of $\mathrm{Al}(\mathrm{OH})^{2+}$ and $\mathrm{Al}(\mathrm{OH})_{2}{ }^{+}$forms were also obtained if a corresponding model was fitted to the data.

(ii) Model B and C: The existence of monomeric species in acid Al solutions has been questioned by many authors (Brosset, 1952; Brosset, Biedermann and Sillén, 1954; Aveston, 1965; Stol, van Helden and de Bruyn, 1976). Brosset et al. (1954) proposed that the main product of hydrolysis is $\left[\mathrm{Al}_{6}(\mathrm{OH})_{1,5}\right]^{3+}($ Model $\mathrm{B})$, whilst Aveston (1965) suggested $\left[\mathrm{Al}_{13}(\mathrm{OH})_{32}\right]^{7+}$ (Model C), together with traces of $\left[\mathrm{Al}_{2}(\mathrm{OH})_{2}\right]^{4+}$.

Our results were also analyzed on the basis of these species as unique hydrolysis products (Table 5), showing that the discrepancies between $C E C$ and $A I$ values are more realistically explained by these models than by assuming the existence of unpolymerized species in Model A. Although precise values cannot be ascribed on the basis of these experiments, apparent 'surface'

Table 4. Supernatant $\mathrm{pH}$ during $\mathrm{Al}$ extraction and the composition of surface-held $\mathrm{Al}$ as unpolymerized ionic species (see text: Model A).

\begin{tabular}{lccccc}
\hline & & \multicolumn{4}{c}{ Model A } \\
\cline { 5 - 7 } & $\begin{array}{c}\mathrm{pH}_{1} \\
(\mathrm{a})\end{array}$ & $\begin{array}{c}\mathrm{pH}_{\mathrm{t}} \\
(b)\end{array}$ & $\begin{array}{c}\% \\
\mathrm{Al}^{3+}\end{array}$ & $\begin{array}{c}\% \\
\mathrm{Al}(\mathrm{OH})^{3+}\end{array}$ & $\begin{array}{c}\% \\
\mathrm{Al}(\mathrm{OH})_{2}{ }^{+}\end{array}$ \\
\hline Kaolin A & 3.3 & 3.0 & 100 & 0 & 0 \\
Kaolin B & 3.2 & 3.0 & 100 & 0 & 0 \\
Montmorillonite & 4.2 & 3.0 & 48 & 52 & 0 \\
Mica & 4.2 & 3.3 & - & - & - \\
Illite & 4.3 & 3.1 & 23 & 77 & 0 \\
Biotite & 3.6 & 3.0 & - & - & - \\
\hline
\end{tabular}

(a) Mean pH up to $2 \mathrm{hr}$ of extraction.

(b) Constant $\mathrm{pH}$ reached during the final extractions. 


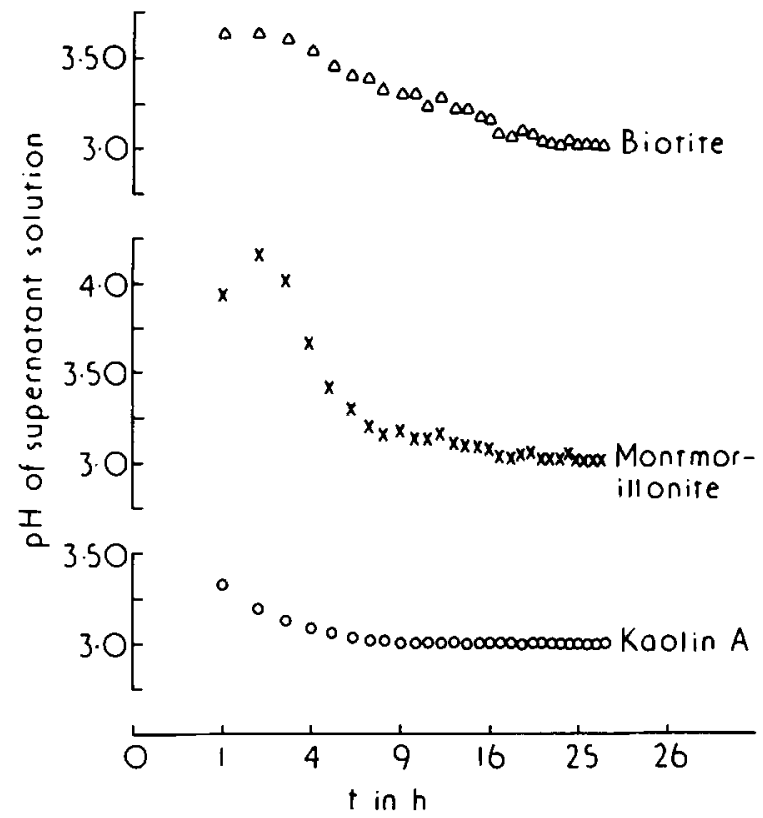

Fig. 3. Progressive change in $\mathrm{pH}$ of the $\mathrm{M} \mathrm{NH}_{4} \mathrm{NO}_{3}$ extract for kaolinite A, montmorillonite, and biotite. (The curve for kaolinite $\mathrm{B}$ is similar to that for kaolinite $A$, and for mica and illite to that for montmorillonite.)

hydrolysis constants for montmorillonite, illite, and biotite were obtained for solid:solution ratios of 1:20 (Table 5) assuming that the adsorbed ions were distributed in the supernatant solution. To calculate this, we also assumed that the $\mathrm{pH}$ of the mineral: $\mathrm{M} \mathrm{NH}_{4} \mathrm{NO}_{3}$ suspension in the reaction period up to $2 \mathrm{hr}$ approximated closely to that resulting from the buffering action of hydrolyzed $\mathrm{Al}$ ions on the mineral surface. The values for the expressions $\log \left[\mathrm{Al}_{6}(\mathrm{OH})_{15}{ }^{3+}\right]-6 \log \left[\mathrm{Al}^{3+}\right]$ and $\log \left[\mathrm{Al}_{13}(\mathrm{OH})_{32}{ }^{7+}\right]-13 \log \left[\mathrm{Al}^{3+}\right]$ were smaller, except for biotite (Figure 4), than those calculated from the hydrolysis constants, $\beta_{15,6}=10^{-47}$ in $2 \mathrm{M} \mathrm{NaClO}_{4}$ at $20^{\circ} \mathrm{C}$ (Brosset et al., 1954) and $\beta_{32,13}=10^{-104.5}$ in $\mathrm{M}$ $\mathrm{NaClO}_{4}$ at $25^{\circ} \mathrm{C}$ (Aveston, 1965). (For the thermodynamic constant $\beta_{15,6^{(0)}}$, Richburg and Adams, 1972, gave a value of $10^{-36}$ at $25-40^{\circ} \mathrm{C}$.) This leads to apparent hydrolysis constants of $\mathrm{Al}$ ions adsorbed at the surfaces of montmorillonite and illite that are smaller than those

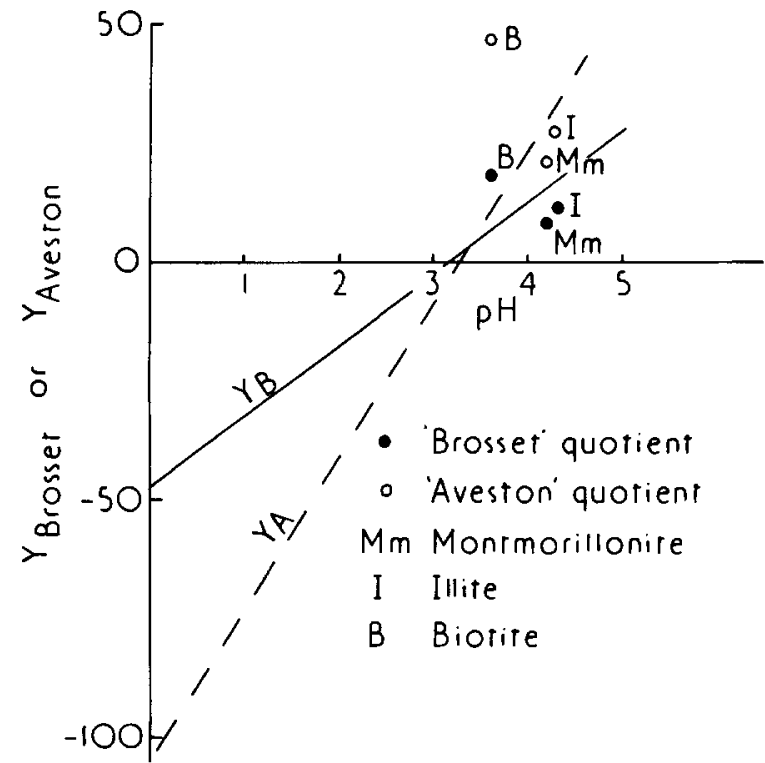

Fig. 4. Relationships between the 'Brosset' $\left(Y_{B}\right)$ and 'Aveston' $\left(Y_{A}\right)$ quotients and $\mathrm{pH}$ (see Table 4). Full line and full circles: Brosset et al. (1954) theory and results, where $Y_{B}=\log \left[\mathrm{Al}_{16}(\mathrm{OH})_{1 i^{3+}}\right]-6 \log \left[\left.\mathrm{Al}\right|^{3+}\right]$ and $\beta_{15.6}=10^{-47}$ in $2 \mathrm{M} \mathrm{NaClO}_{4}$ at $20^{\circ} \mathrm{C}$. Broken line and open circles: Aveston (1965) theory and results, where $Y_{A}=\log \left[\mathrm{Al}_{{ }_{13}}(\mathrm{OH})_{32}{ }^{7+}\right]-13$ $\log \left[\mathrm{Al}^{3+}\right]$ and $\beta_{32,13}=10^{-104.5}$ in $\mathrm{M} \mathrm{NaClO}_{4}$ at $25^{\circ} \mathrm{C}$. ( $\mathrm{Mm}=$ montmorillonite; $\mathrm{I}=$ illite; $\mathrm{B}=$ biotite.)

of $\mathrm{Al}$ ions in solution (cf. Low, 1955, for H-Al bentonite, Lim and Talibudeen, 1975, for acid soils, and Pyman et al., 1975, for Al bentonite). For biotite, however, the larger values of $\beta_{15,6}=10^{-36}$ and $\beta_{32,13}=$ $10^{-68}$ result from abnormally large values of $\mathrm{Al}$ determined in the equilibrium solution compared with those predicted by the 'Brosset et al.' and 'Aveston' $\beta$ constants quoted above, suggesting that the correction for $\mathrm{Al}$ in the solution entrained during sample preparation was underestimated in the experiment.

\section{ACKNOWLEDGMENTS}

F. Cabrera thanks the Ramsay Memorial Fellowships Trust and the Consejo Superior de Investigaciones Cientifícas (C.S.I.C.) for financial support. Mrs. I. Jasko and Mr. V. Cosimini provided $\mathrm{N}$ analysis.

Table 5. Composition and apparent hydrolysis constants of surface-held Al calculated from Models B (Brosset et al., 1954) and C (Aveston, 1965).

\begin{tabular}{|c|c|c|c|c|c|c|}
\hline & \multicolumn{3}{|c|}{ Model B } & \multicolumn{3}{|c|}{ Model C } \\
\hline & $\mathrm{Al}^{\mathbf{3}^{3+}}$ & $\mathrm{Al}_{6}(\mathrm{OH})_{15^{3+}}$ & \multirow{2}{*}{$\begin{array}{c}\beta_{15,6} \\
\text { (a) }\end{array}$} & $\mathrm{Al}^{3+}$ & $\mathrm{Al}_{13}(\mathrm{OH})_{32}{ }^{7+}$ & \multirow{2}{*}{$\frac{\beta_{32,13}}{(b)}$} \\
\hline & \multicolumn{2}{|c|}{ millimole $\mathrm{kg}^{-1}$} & & \multicolumn{2}{|c|}{ millimole $\mathbf{~ k g}^{-1}$} & \\
\hline Montmorillonite & 234.0 & 10.3 & $10^{-54.7}$ & 233.0 & 4.9 & $10^{-112.8}$ \\
\hline Illite & 73.5 & 5.5 & $10^{-53.5}$ & 73.0 & 2.6 & $10^{-109.8}$ \\
\hline Biotite & 5.5 & 12.2 & $10^{-35.8}$ & 2.3 & 5.7 & $10^{-67.6}$ \\
\hline
\end{tabular}

(a) $\beta_{15.6}=10^{-47}$ in $2 \mathrm{M} \mathrm{NaClO}_{4}$ at $20-40^{\circ} \mathrm{C}$ (Brosset et al., 1954).

(b) $\beta_{32,13}=10^{-104.5}$ in $\mathrm{M} \mathrm{NaClO}{ }_{4}$ at $25^{\circ} \mathrm{C}$ (Aveston, 1965). 


\section{REFERENCES}

Aveston, J. (1965) Hydrolysis of aluminium ion: Ultracentrifugation and acidity measurement: J. Chem. Soc. 4438-4443.

Bache, B. W. (1970) Barium isotope method for measuring cation-exchange capacity of soils and clays: J. Sci. Food. Agric. 21, 169-171.

Bache, B. W. (1974) Soluble aluminium and calcium-aluminium exchange in relation to the $\mathrm{pH}$ of dilute calcium chloride suspensions of acid soils: J. Soil Sci. 25, 320-332.

Bache, B. W. and Sharp, G. S. (1976a) Characterisation of mobile aluminium in acid soils; Geoderma 15, 91-101.

Bache, B. W. and Sharp, G. S. (1976b) Soluble polymeric hydroxyaluminium ions in acid soils: $J$. Soil $S c i .27,167-174$.

Brosset, C. (1952) On the reactions of the aluminium ion with water: Acta Chem. Scand. 6, 910-940.

Brosset, C., Biedermann, G. and Sillén, L. G. (1954) Studies of the hydrolysis of metal ions. XI. The aluminium ion, $\mathrm{Al}^{3+}$; Acta Chem. Scand. 8, 1917-1926.

Brown, G. and Newman, A. C. D. (1973) The reactions of soluble aluminium with montmorillonite: $J$. Soil Sci. 24, 337-354.

Cabrera, F. and Talibudeen, O. (1977) Effect of soil $\mathrm{pH}$ and organic matter on labile aluminium in soils under permanent grass: $J$. Soil Sci. 28, 259-270.

Chakravarti, S. N. and Talibudeen, O. (1961) Phosphate interaction with clay minerals: Soil Sci. 92, 232-242.

Coulter, B. S. (1969) The chemistry of hydrogen and aluminium ions in soils, clay minerals and resins: Soils Fert. 32, 215-223.

Crank. J. (1956) The Mathematics of Diffusion: Oxford University Press, Oxford.

Dalal, R. C. (1975) Hydrolysis products of solution and exchangeable aluminium in acidic soils: Soil Sci. 119, 127-131.

Jackson, M. L., Tyler, S. A., Willis, A. L., Bourbeau, G. A. and Pennington, R. P. (1948) Weathering sequence of clay-size minerals in soils and sediments. I. Fundamental generalizations: J. Phys. Colloid. Chem. 52, 1237-1260.

Jackson, M. L., Hseung, Y., Corey, R. B., Evans, E. J. and Vanden Heuvel, R. C. (1952) Weathering sequence of clay-size minerals in soils and sediments. II. Chemical weathering of layer silicates: Soil Sci. Soc. Am. Proc, 16, 3-6.

Jayman, T. C. Z. and Sivasubramaniam, S. (1974) The use of ascorbic acid to eliminate interference from iron in the aluminon method for determining aluminium in plant and soil extracts: Analyst London 99, 296-301.

Lim, T. S. and Talibudeen, O. (1975) The behaviour of exchangeable aluminium in acid soils: Rothamsted Exp. Stn. Rep. Part 1, p. 87.

Lin, C. and Coleman, N. T. (1960) The measurement of exchangeable aluminium in soils and clays: Soil Sci. Soc. Am. Proc. 24, 444-447.

Low, P. F. (1955) The role of aluminum in the titration of bentonite: Soil Sci. Soc. Am. Proc. 19, 135-139.

Prakash, J. B. S. and Bhasker, T. D. (1974) Exchangeable aluminium and phosphorus sorption of some acid soils of Mysore State. Soil Sci. 118, 243-246.

Pyman, M. A. F., Posner, A. M. and Talibudeen, O. (1976) Hydrolysed aluminium ions on montomorillonite: Rothamsted Exp. Stn. Rep. Part 1, pp. 94-95.

Rawson, R. A. G. (1969) A rapid method for determining the surface area of aluminosilicates from the adsorption dynamics of ethylene glycol vapour: J. Soil Sci. 20, 325-335.

Richburg, J. S. and Adams, F. (1970) Solubility and hydrolysis of aluminium in soil solutions and saturated-paste extracts. Soil Sci. Soc. Am. Proc. 34, 728-734.

Sivasubramaniam, S. and Talibudeen, O. (1972) K-Al exchange in acid soils. I. Kinetics: J. Soil Sci. 23, 163-176.

Skeen, J. B. and Sumner, M. E. (1967) Exchangeable aluminium. Part I. The efficiency of various electrolytes for extracting aluminium from acid soils: $S$. Afr. J. Agric. Sci. 10, 3-10.

Smith, B. H. and Emerson, W. W. (1976) Exchangeable aluminium on kaolinite: Aust. J. Soil Res. 14, 43-53.

Stol, R. J., Van Helden, A. K. and de Bruyn, P. L. (1976) Hydrolysisprecipitation studies of aluminium (III) solutions. 2. A kinetic study and model: $J$. Colloid Interface Sci. 57, 115-131.

Talibudeen, O. and Weir, A. H. (1972) Potassium reserves in a 'Harwell' series soil: $J$. Soil $S_{c i}$. 23, 456-474.

Резюме- Скорости высвобождения $\mathrm{Al}$ с помощью $\mathrm{M} \mathrm{NH}_{4} \mathrm{NO}_{3}$ ( $\mathrm{pH}$ 3) из минералов, насыненных ионами Al при $\mathrm{pH}=3$ позволяет предположить, что ионы Al мигрировали из поверхностных слоев и изнутри образцов каолинита, монтмориллонита, иллита и биотита, но только изнутри образцов слюды мусковита. Из 0.25-0.5 нм каолинита и монтмориллонита, часть "поверхностного" Аl высвобождается "моментально" и остальной-согласно кинетике первого порядка,но грубозернистый

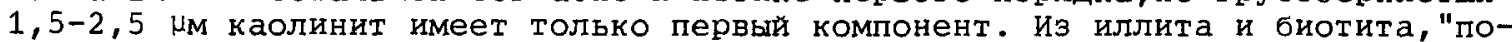
верхностный" Al высвобождается согласно "объемной дифФузионной"кинетике, предполагающей существование наружных периферийных слоев ограниченной мощ-

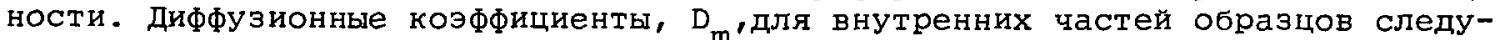
ют тенденции: слюда ббитит >иллит >монтмориллонит >Каолинит .

На основе моделей, предложенных в предыдущей работе,был вычислен ионный состав "поверхностного" А1. Эти вычисления показывают уто 1/ этот состав изменяется в соответствии с минералом от 3 до $100 \%$ A 1 , остальная часть находится в гидролизной форме и 2/ удельные гидролизные постоянные различны для каждого минерала и значительно отличаются от этих же параметров для ионов AI в растворе. 
Kurzreferat- Die Geschwindigkeiten,mit denen Al durch 1 molare Ammoniumnitratlösung,bei $\mathrm{pH} 3$ aus mit Al gesätigten Mineralien gelöst wird, deutet darauf hin, daß Al Ionen von den oberflächen und den Gesteinsinnern von Kaolinit, Montmorillonit, Illit und Biotit, aber nur vom Innern des MuskowitGlimmer,freigesetzt werden. Von den $0,25-0,5 \mu \mathrm{m}$ Kaoliniten und Montmorilloniten wird ein Teil des oberfächen-Al unverzüglich herausgelöst und der Rest folgt Kinetik erster Ordnung; grobes, $1,5-2,5 \mu \mathrm{m}$ Kaolinit jedoch besitzt nur die erstere Romponente. Von Illit und Biotit wird Oberflächen-Al via Massendiffusionskinetik freigesetzt, was auf die Existenz einer veränderten peripheren Schicht mit begrenzter Dicke hindeutet. Die Diffusionskoeffizienten, $D_{m}$, für das Gesteinsinnere haben die folgende Tendenz: Glimmer $\simeq$ Biotit > Illit > Montmorillonit > Kaolinit.Auf Basis von vorgeschlagenen Modellen von früherer Arbeit, wird die ionische Zusammenstellung des oberflächen Al berechnet. Damit wird gezeigt, (1) die Zusammensetzung variiert mit dem Mineral von 3 bis $100 \% \mathrm{Al}$ (III), mit dem Rest in hydrolisierter Form; und (2) die scheinbaren Hydrolysenkonstanten sind unterschiedlich für jedes Mineral und sehr anders als die Konstanten für Al-Ionen in Lösung.

Résumé-Les vitesses de libération de l'Al par $\mathrm{M} \mathrm{NH}_{4} \mathrm{NO}_{3}$ (pH 3 ) d'ions saturés d'Al à un $\mathrm{pH}$ de 3 suggère que les ions d'Al ont émigré des couches de surface et du noyau de la matrice de kaolinite, d'illite et de biotite, mais seulement du noyau de la matrice de mica muscovite. De $0.25-0.5 \mathrm{~m}$ de kaolinite et de montmorillonite, une partie de l'Al "de surface" est libérée "instantanément" et le reste par cinétique de premier ordre; mais la kaolinite grossière de 1.5-2.5um est entiêrement libérée "instantanément". L'Al de surface est libérée par "diffusion en masse" cinétique de l'illite et de la biotite,suggérant l'existence de couches déformées d'épaisseur finie.Les coefficients de diffusion,Dm, suivent la tendance suivante pour le noyau de la matrice:

mica $\cong$ biotite $>$ illite $>$ mon tmorillonite $>$ kaolinite.

En se basant sur des modèles proposés dans une étude précédente,la composition ionique de l'Al de "surface" est calculée.Ceci montre que (1) cette composition varie d'après le minéral de 3 à 100 o d'Al, le restant étant dans une forme hydrolysée et (2) les constantes d'hydrolyse sont différentes pour chaque minéral et diffèrent d'une manière significative de celles d'ions d'Al en solution. 